Article

\title{
The Relationships among Transformational Leadership, Professional Learning Communities and Teachers' Job Satisfaction in China: What Do the Principals Think?
}

\author{
Jia Zhang ${ }^{1}\left(\mathbb{D}, Q^{2 i n a n}\right.$ Huang ${ }^{1}\left(\mathbb{D}\right.$ and Jianmei $X u^{2, *(\mathbb{D})}$ \\ 1 College of Education, Zhejiang University, Hangzhou 310058, China; jiazhang2015@zju.edu.cn (J.Z.); \\ 22003026@zju.edu.cn (Q.H.) \\ 2 Jing Hengyi School of Education, Hangzhou Normal University, Hangzhou 310058, China \\ * Correspondence: 20090111@hznu.edu.cn
}

check for

updates

Citation: Zhang, J.; Huang, Q.; Xu, J.

The Relationships among

Transformational Leadership,

Professional Learning Communities

and Teachers' Job Satisfaction in

China: What Do the Principals

Think? Sustainability 2022, 14, 2362.

https://doi.org/10.3390/su14042362

Academic Editor: Jesús-Nicasio

García-Sánchez

Received: 24 January 2022

Accepted: 15 February 2022

Published: 18 February 2022

Publisher's Note: MDPI stays neutral with regard to jurisdictional claims in published maps and institutional affiliations.

Copyright: (c) 2022 by the authors. Licensee MDPI, Basel, Switzerland. This article is an open access article distributed under the terms and conditions of the Creative Commons Attribution (CC BY) license (https:// creativecommons.org/licenses/by/ $4.0 /)$.

\begin{abstract}
This study explores the relationships among transformational leadership, professional learning community (PLC) components, and teachers' job satisfaction from Chinese principals' perspective. A survey was conducted among 572 principals from different provinces in China. Structural equation modelling results revealed that transformational leadership had a significant effect on all five components of PLCs (i.e., shared purpose, collaborative activity, collective focus on student learning, deprivatized practice, and reflective dialogue), and these five PLC components all significantly predicted teachers' job satisfaction. Meanwhile, the effect of transformational leadership on teachers' job satisfaction was also significant. Mediation analysis showed that all five components of PLCs were significant mediators between transformational leadership and teachers' job satisfaction. The practical implications of the findings and suggestions for future research are also discussed.
\end{abstract}

Keywords: professional learning communities; transformational leadership; teachers' job satisfaction; China

\section{Introduction}

The concept of professional learning communities (PLCs) has been a widely discussed topic in the education field since the 1990s. By creating a beneficial environment for teachers' collective learning and inquiry, PLCs hold promise for enhancing school reform [1,2], teacher development $[3,4]$, teaching practice $[5,6]$, and student learning $[7,8]$. The tenet of PLCs, i.e., collaboration, is also regarded to be a key characteristic of teachers for Education 4.0 coming with the Fourth Industrial Revolution, which supports digital transformation and virtualization processes [9]. Consequently, establishing PLCs is an important strategy to promote educational reform in many countries such as the USA, Australia, and Singapore $[10,11]$.

In the past few decades, studies have investigated the concept and practice of PLCs from various angles. First, various conceptual models of PLCs were put forward to understand their characteristics in different contexts [12,13], and models were also validated by empirical studies $[14,15]$. Furthermore, research devoted considerable attention on how to establish effective PLCs. Various stages for the development of PLCs were identified [16], and the crucial role of principal leadership in implementing PLCs and promoting professional development is consistently highlighted [17-19]. In addition, studies have explored the effects of PLCs on teachers and students. They found that PLCs can lead to teachers' enhanced teaching effectiveness [6] and reduced sense of isolation [20], and increased student achievement [8]. Although studies on PLCs have been increasing in recent years, significant research gaps exist in the literature. First, previous research has devoted lots of attention to the characteristics of PLCs and how to develop and sustain PLCs, but studies on their antecedents and consequences remain limited. Particularly, 
research highlighted the crucial role of principal leadership on PLC practice [21-23], but the relationships between various types of leadership, especially transformational leadership and PLCs, need more empirical studies. In addition, although research indicates that PLCs positively affect teachers' teaching practice and student achievement [6,24], scant studies focus on their effects on teachers' psychological wellbeing such as their job satisfaction.

Second, most existing research on the role of school organizational factors in PLCs and the influence of PLCs on teachers is based on Western settings, and their conclusions are often taken for granted by scholars in other educational contexts. Considering that sociocultural context matters a lot to the practice of PLCs [2,15], it is important to examine the antecedents and consequences of PLCs in non-Western contexts such as China, where teacher collaboration has existed in schools for almost seventy years. In the literature, although a number of studies have explored teachers' collaborative practices in Chinese schools from the perspective of PLCs, few studies investigate their antecedents and consequences.

Third, the majority of research on PLCs, especially quantitative research, relies on teachers' perceptions [22,25], while principals' perspective is ignored. Investigating PLCs from the perspective of principals is significant, as it can help enrich our knowledge of the complexity of PLC development from the angle of school improvement [26]. For example, Zhang et al. [27] found that there was difference between school leaders' and teachers perspectives regarding challenges to the practice of PLCs. Thus, more research is needed to explore the development of PLCs from principals' perspective.

To fill in these research gaps, the current study explores the antecedents and consequences of PLCs perceived by principals in China. Social support theory is further applied to frame the study. According to social support theory, social support involves exchanges between individuals based on the reciprocity principle, i.e., a person would return a benefit when they receive support from others, and if they feel that they are unable to give back to the support provider, they are less likely to seek help or may try to assist others beyond the provider, which can increase the welfare of the beneficiary [28]. In a school setting, it is common that teachers seek help from the principal in performing collaborative activities in PLCs. The principals' reform initiative, as mostly reflected in their transformational leadership, can provide support and help for teachers to transform their school into a PLC [29]. To return the received benefit, teachers may pursue supporting and helping each other or their students, which can enhance their wellbeing such as job satisfaction [30].

Guided by the social support theory, we chose transformational leadership as the antecedent of PLCs in this study, which plays a key role in teachers' team learning and team performance [31,32]. However, the link between transformational leadership and PLCs is seldom examined in the Chinese context. For the consequence of PLCs, we chose teachers' job satisfaction, an important indicator of school effectiveness and student achievement [33,34]. Meanwhile, for PLCs, we distinguish their various components, as studies [35] found that some components of PLCs positively affect student achievement, while others have a negative influence. Therefore, this study explores the relationships among transformational leadership, PLC components, and teachers' job satisfaction in China. Accordingly, four research questions are put forward: (1) Does transformational leadership affect PLC components? (2) Do PLC components affect teachers' job satisfaction? (3) Does transformational leadership affect teachers' job satisfaction? (4) Do PLC components mediate the effects of transformational leadership on teachers' job satisfaction?

\section{Literature and Hypotheses}

\subsection{PLCs in Chinese Context}

PLC is considered to be a loose concept with various interpretations in different contexts [2,8], and is used interchangeably with the terms "professional community" [36] and "learning community" [16]. A PLC is generally defined as a group of educators engaging in the continuous and collaborative sharing, investigation, and improvement of their professional practice with an aim of enhancing student learning [2,12]. In practice, PLCs can 
take various forms, such as study groups [12], lesson study [37], and action research [38], which could be implemented at the department [3], school [39] and system [30] levels.

Despite their varying conceptualizations, some basic characteristics of PLCs have been identified: (1) shared purpose, referring to teachers sharing a common purpose regarding teaching and learning [40,41]; (2) a collective focus on student learning, referring to teachers' professional activities unswervingly focusing on how to improve student learning [6,30]; (3) collaborative activity, referring to teachers working together to plan, investigate, reflect on, and improve their teaching practices [11,39]; (4) deprivatized practice, referring to teachers' sharing of practices such as peer observations, open lessons, and teamed teaching structures [12,14]; (5) reflective dialogue, referring to teachers engaging in indepth conversations about the progress of their instructional practice to improve teaching and learning [2,42]. Such a conceptualization was endorsed by Louis and Kruse [36], Leithwood et al. [43], and Lomos et al. [8], and it has been applied in the Chinese context, and showed good reliability and construct validity.

In Chinese schools, there is a long history of teacher collaboration, although the concept of PLCs was introduced from the West. As early as the 1950s, as required by the Ministry of Education of China, TRGs that consist of teachers of the same subject were established in Chinese schools with an aim of improving teaching practices [44]. In TRGs, various types of collaborative learning activities are regularly organized, including joint lesson planning, collective preparation and observations of open lessons with postlesson discussions, peer observation and peer coaching, and collaboratively conducting action research. These activities allow for teachers to work together to reflect on and improve teaching and learning [45]. Therefore, collaborative activities in TRGs are the most important way of teachers' professional learning and development [46].

Researchers have debated whether TRGs can be called PLCs. As TRGs are not spontaneously established by teachers but deliberately organized under the directive of education authorities, some researchers [47] claimed that TRGs represented "contrived collaboration" (p. 626). Nonetheless, the above authentic professional activities predominate in TRGs, and they are effective in improving teaching and student learning [48]. Thus, they are highly regarded and appreciated by teachers [15]. In this sense, TRGs present the essential features of PLCs such as shared values, collaborative learning, and a focus on student learning [15]. Recent studies $[49,50]$ also repeatedly indicated that TRGs are characterized by teachers genuine collegiality, mutual sharing, and shared responsibility for the improvement of teaching and learning. Following this view, we consider TRGs to be a Chinese version of PLCs in the current study.

A growing number of studies used the concept of PLCs to examine teachers' collective activities in TRGs [51]. Studies investigated the characteristics and context specificity of PLCs [13,15,50], barriers in the development of PLCs [27], the development of PLCs among schools in various districts [15], and how teachers learn together in PLCs [52]. However, few empirical studies have been conducted on the antecedents and consequences of PLCs, particularly those from principals' perspective [51]. In this study, we explore the relationships among transformational leadership, PLC components, and teachers' job satisfaction from Chinese principals' perspective.

\subsection{Transformational Leadership and PLCS}

As a change-oriented leadership style, transformational leadership refers to "the process through which leaders and followers help each other to advance to a higher level of morality and motivation" [53] (p. 21). Transformational leaders are committed to motivating and empowering teachers and teacher groups towards school change and teaching improvement [54,55]. Researchers have developed various models of transformational leadership. Bass [56] proposed three dimensions of transformational leadership, namely, vision building, providing individual support, and providing intellectual stimulation. Yukl [57] identified four aspects of transformational leadership, i.e., individualized consideration, intellectual stimulation, idealized influence, and inspirational motivation. By addressing 
the weaknesses of these models [56,57], such as ambiguity about leadership behaviors, Leithwood and Jantzi [58] further conceptualized transformational leadership into three broad categories, namely, setting directions, developing people, and redesigning the organization. Among them, setting direction refers to building vision, developing goals and establishing high expectations; developing people refers to stimulating intelligence, providing individualized support, and setting examples in terms of values and practices; redesigning the organization refers to developing collaborative structures, cultures, and relationships to help teachers in participating in school affairs.

Previous studies consistently showed the positive effect of principal leadership on PLC development [23,59,60]. For instance, Buttram and Farley-Ripple's [21] mixed-method study revealed that principals affect both what teachers undertake in PLCs and how well they carry out these activities. Using survey data from 32 Hong Kong primary schools, Hallinger et al. [22] found that principals play a crucial role in the development of PLCs. The positive relationships between various types of principal leadership and PLCs have also been reported. Distributed leadership is considered to be a key factor in creating and maintaining PLCs [11,30,61], and a number of case studies [62-64] demonstrated how principals' distributed leadership supported the sustainment of PLCs. Instructional leadership also contributes to the practice of PLCs. For example, The study of Hassan et al. [65] on teachers in Malaysia found that instructional leadership helped nurture a culture required by PLCs. The study of Vanblaere and Devos [25] on Flemish teachers indicated that instructional leadership was associated with teachers' deprivatized practice and reflective dialogue. Although research [29] indicated that principals who exhibited features of transformational leadership were more likely to successfully implement PLCs, the link between transformational leadership and PLCs needs further empirical investigations.

In the context of mainland China, the effect of principal leadership on PLCs has been explored in several recent studies. For instance, Zheng et al. [66] reported significant influences of instructional leadership on all the components of PLCs. Wang [67] also suggested that instructional leadership played a critical role in developing a shared vision, a culture of trust, and collegial learning among teachers. Yin and Zheng [68] found that leadership practices had positive effects on PLCs. However, few studies have focused on the relationship between transformational leadership and PLCs. Moreover, existing research has chiefly leaned upon teacher perceptions, and how principals perceive the relationship between leadership and PLCs is seldom examined. Therefore, we put forward the following hypothesis: principals' transformational leadership has a positive effect on PLC components (Hypothesis 1).

\subsection{Teachers' Job Satisfaction and Its Antecedents}

Job satisfaction is defined as "the pleasurable emotional state resulting from the appraisal of one's job as achieving or facilitating one's job values" [69] (p. 316). Teachers' job satisfaction reflects their affective relation to the teaching role and a function of the relationship between what they want from teaching and what they perceive it offers to them [70]. Studies found that teachers' job satisfaction is a key predictor of school improvement [34], as it can positively affect teachers' classroom teaching [71] and commitment to student learning [72], and negatively affect their job stress [73] and burnout [74].

Previous research has identified a number of antecedents of teachers' job satisfaction. First, teacher characteristics such as gender, teaching experience, and career status [75-77], and school characteristics such as school level and type [77,78] can affect teachers' job satisfaction. Second, various leadership styles such as distributed leadership $[79,80]$, instructional leadership [80], servant leadership [81], and transformational leadership [72,82] were positively associated with teachers' job satisfaction. Third, other organizational factors such as school climate [83], working conditions [84], organizational support [85] and teacher trust [86], autonomy [87], and efficacy [88] also influence teachers' job satisfaction. 
Nonetheless, the majority of research on the antecedents of teachers' job satisfaction is based on Western contexts, and studies on how various factors, especially principal leadership, affect teachers' job satisfaction in China are limited. Considering that teachers in Shanghai, China ranked high in job satisfaction in the 2018 Teaching and Learning International Survey (TALIS), it is important to explore the relationship between transformational leadership and teachers' job satisfaction to enrich our understanding of the influence of principal leadership on teachers in China. Therefore, we propose the second hypothesis: principals' transformational leadership has a positive effect on teachers' job satisfaction (Hypothesis 2).

Although various influencing factors of teachers' job satisfaction have been identified, empirical studies on the links between PLCs and teachers' job satisfaction are limited. Scholars claimed that teachers are more satisfied when engaging in PLCs [12,30], and qualitative research [89] indicated that PLCs provided a favorable environment for teachers' mutual exchange, and thus enhance their satisfaction. In China, some studies [90,91] showed that teachers' collective inquiry and sharing and shared purpose and responsibility can significantly and positively affect teachers' job satisfaction, but other studies [92] found that only part of PLC components, i.e., shared sense of purpose, deprivatized practices and reflective dialogue, had positive effects on teacher satisfaction, while collective focus on student learning had no effect on teacher satisfaction, and collaborative activity had a negative effect on teachers' job satisfaction. The inconsistent results call for more empirical research on the relationships between PLC components and teachers' job satisfaction. As PLCs have an effect on teacher efficacy $[66,90]$, and teacher efficacy can predict their job satisfaction [88], we propose a third hypothesis: PLC components have positive effects on teachers' job satisfaction (Hypothesis 3).

\subsection{Mediating Role of PLCs}

Studies have reported the mediating role of teacher collaboration or PLCs in the effects of principal leadership on teachers. For example, the study of Goddard et al. [93] indicated that teacher collaboration served as a mediator between instructional leadership and teachers' collective efficacy. Similarly, Torres [79] found that teachers' professional collaboration mediated the effect of distributed leadership on their job satisfaction. Joo's [94] study showed that distributed leadership indirectly influenced teacher professionalism through their participating in PLCs. Luyten and Bazo [95] found that the effect of transformational leadership on teaching practices was indirect and mainly through PLCs and teacher learning. Voelkel's [96] study revealed that transformational leadership predicted PLCs, which further predicted teacher collective efficacy. The study of Zheng et al. [66] on teachers in mainland China suggested that PLCs had a mediating effect on the relationship between instructional leadership and teacher self-efficacy. On the basis of these findings, we can speculate that PLCs mediate the effect of transformational leadership on teachers' job satisfaction, as shown in the following hypothesis: PLC components mediate the effects of transformational leadership on teachers' job satisfaction (Hypothesis 4).

The theoretical framework of the study is illustrated in Figure 1, in which transformational leadership is hypothesized to positively affect PLC components (H1); transformational leadership is hypothesized to positively affect teachers' job satisfaction (H2); PLC components are hypothesized to positively affect teachers' job satisfaction (H3); and PLC components are hypothesized to mediate the effects of transformational leadership on teachers' job satisfaction $(\mathrm{H} 4)$. 


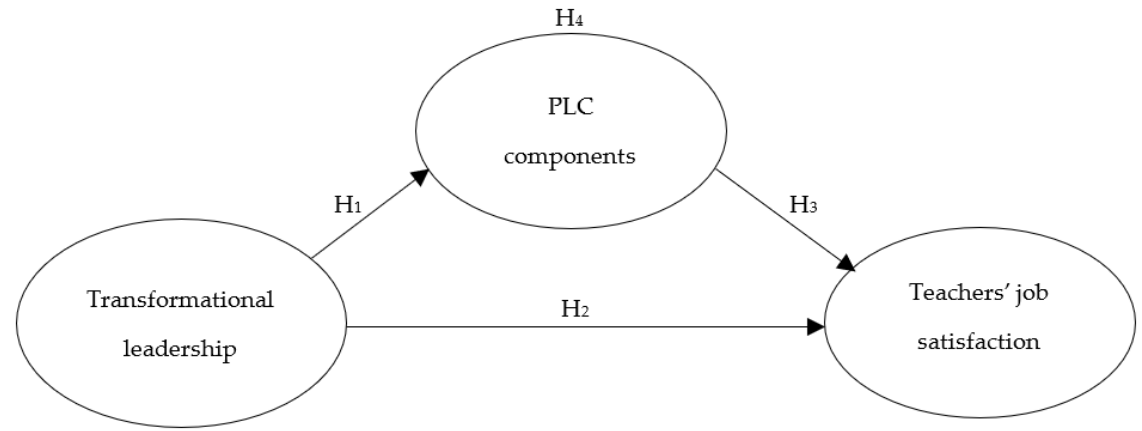

Figure 1. Theoretical framework.

\section{Methodology}

Before collecting the data, the first author had applied for the ethics approval from the institutional research ethics committee. The research ethics approval of the study was obtained after all the purposes, instruments, and procedures had been scrutinized by the committee.

\subsection{Participants}

A questionnaire survey of principals from different provinces in China was conducted in this study. In total, 800 questionnaires were distributed, and 572 valid copies were returned, providing a useful return rate of $71.5 \%$. Specifically, 52.3\% (299) of the principals came from eastern developed areas, and 47.7\% (273) came from less developed areas in central and western China, 45.0\% (257) of them were from urban schools, and 55.0\% (315) were from suburban and rural schools. The participants consisted of $68.4 \%$ (391) males and $31.6 \%$ (181) females. Among them, 12.6\% (72) were 40 years old or younger, 64.7\% (370) were between 41 to 50 years old, and 22.7\% (130) were 51 years old or older. In addition, $37.2 \%$ (213) of the participants worked in elementary schools (grades 1 to 6), 34.8\% (199) worked in middle schools (grades 7 to 9), 13.3\% (76) worked in high schools (grades 10 to 12 ), and $15.0 \%$ (84) worked in other schools such as nine-year education schools (grades 1 to 9 ) and secondary schools (grades 7 to 12 ). With regard to their position, $47.6 \%$ (272) were principals, and the other $52.0 \%$ (300) were deputy principals.

\subsection{Instruments}

The questionnaire consisted of three scales, namely, the transformational leadership (TL) scale, the professional learning community (PLC) scale, and the teachers' job satisfaction (TJS) scale. The questionnaire was designed in Chinese, the mother tongue of the participants, to aid them in better understanding the items. The 9-item TL scale adapted from Leithwood and Jantzi [58] comprises three subscales: setting directions (SD, three items), developing people (DP, three items), and redesigning the organization ( $\mathrm{RO}$, three items). This scale was used [97] in the Chinese context, and showed good psychometric results in terms of reliability and construct validity. The 18-item PLC scale adapted from Leithwood et al. [43] contains five subscales: shared sense of purpose (SP, three items), collaborative activity (CA, five items), collective focus on student learning (CFSL, four items), deprivatized practice (DPr, four items), and reflective dialog (RD, two items). This scale was used by Zheng et al. $[66,98]$ in the Chinese context, and showed good psychometric results in terms of reliability and construct validity. The 7-item TJS scale was adapted from Ostroff [33]. The principals were requested to rate the items of the three scales on a 5-point Likert scale ranging from "strongly disagree" to "strongly agree". Specific items are shown in Appendix A.

These three scales were originally employed to measure teachers' perceptions on the specific items, and they were adapted according to the principals' perspective in the current study. For example, an item from TL scale, i.e., "provide useful assistance to you in setting short-term goals for teaching and learning" (teacher questionnaire), was adapted to "I 
provide useful assistance to teachers in setting short-term goals for teaching and learning" (principal questionnaire). The principals were requested to rate the same set of items in the teacher questionnaire, but rephrased according to the principals' perspective. To ensure the quality of adaption, the authors conducted several rounds of discussion and finally reached an agreement. Five principals were also enquired about the expressions of the items to guarantee that their meaning was accurate and clear.

\subsection{Analysis}

SPSS 22.0 and Amos 24.0 were used to analyze the data. First, confirmatory factor analysis (CFA) was conducted using Amos to examine the construct validity of the three scales. Convergent validity (average variance extracted value, AVE), discriminant validity (square root of AVE is greater than correlations among the latent variables), internal consistency reliability (Cronbach's alpha coefficient), and composite reliability (CR) were also examined. Descriptive statistics were then calculated by SPSS. After that, structural equation modelling (SEM) was conducted using Amos to investigate the relationships among transformational leadership, PLC components, and teachers' job satisfaction. For CFA and SEM analysis, a number of standard indices were used to indicate the robustness of fit, namely, the chi-squared statistic $\left(\chi^{2}\right)$, root mean square error of approximation (RMSEA), comparative fit index (CFI), and Tracker-Lewis index (TLI). Following Kline's [99] suggestion, RMSEA $\leq 0.06$ (0.08), CFI $\geq 0.95$ (0.90), and TLI $\geq 0.95$ (0.90) were used as cutoffs for indicating good (or acceptable) data fit. For mediation analysis, bootstrap was used to detect indirect effects [100].

\section{Results}

\subsection{Scale Reliability and Validity}

The construct validity of each scale was tested by CFA. For the transformational leadership scale, because our hypotheses focused on the whole construct of transformational leadership instead of its subdimensions, we performed a second-order CFA to examine its construct validity. The result suggested a satisfactory data fit: $\chi^{2}=96.86, \mathrm{df}=23, p<0.001$, RMSEA $=0.075, \mathrm{CFI}=0.98, \mathrm{TLI}=0.97$, and all the factor loadings for the latent variables were significant (ranging from 0.67 to 0.92 ). Table 1 shows that the Cronbach's alpha coefficient of the main transformational leadership scale (0.92) was higher than 0.90, AVE value (0.88) was higher than 0.50 , and CR value (0.96) was higher than 0.70 . Therefore, the transformational leadership scale had good construct validity, convergent validity, and reliability.

Table 1. Descriptive statistics, correlation matrix, Cronbach's $\alpha$, AVE, CR, and square root of AVE.

\begin{tabular}{cccccccc}
\hline & $\mathbf{1}$ & $\mathbf{2}$ & $\mathbf{3}$ & $\mathbf{4}$ & $\mathbf{5}$ & $\mathbf{6}$ \\
\hline 1. TL & 1 & & & & & \\
2. SP & $0.48^{* *}$ & 1 & & & & \\
3. CA & $0.48^{* *}$ & $0.69^{* *}$ & 1 & & & \\
4. CFSL & $0.49^{* *}$ & $0.65^{* *}$ & $0.67^{* *}$ & 1 & & \\
5. DPr & $0.45^{* *}$ & $0.57^{* *}$ & $0.68^{* *}$ & $0.65^{* *}$ & 1 & \\
6. RD & $0.44^{* *}$ & $0.63^{* *}$ & $0.72^{* *}$ & $0.67^{* *}$ & $0.75^{* *}$ & 1 \\
7. TJS & $0.38^{* *}$ & $0.54^{* *}$ & $0.56^{* *}$ & $0.50^{* *}$ & $0.49^{* *}$ & $0.52^{* *}$ & 1 \\
M & 4.34 & 4.24 & 4.26 & 4.33 & 4.28 & 4.34 & 3.98 \\
SD & 0.59 & 0.69 & 0.69 & 66 & 0.71 & 0.74 & 0.67 \\
$\alpha$ & 0.92 & 0.91 & 0.93 & 0.89 & 0.87 & 0.91 & 0.91 \\
AVE & 0.88 & 0.76 & 0.74 & 0.68 & 0.71 & 0.84 & 0.62 \\
CR & 0.96 & 0.90 & 0.94 & 0.89 & 0.88 & 0.91 & 0.92 \\
square root of AVE & - & 0.87 & 0.86 & 0.82 & 0.84 & 0.92 \\
\hline
\end{tabular}

Note: ${ }^{* *} p<0.01, \mathrm{TL}=$ transformational leadership, $\mathrm{SP}=$ shared purpose, $\mathrm{CA}=$ collaborative activity, $\mathrm{CFSL}=$ collective focus on student learning, $\mathrm{DPr}=$ deprivatized practice, $\mathrm{RD}=$ reflective dialogue, TJS $=$ teachers' job satisfaction. 
For the PLC scale, the CFA result showed a satisfactory data fit: $\chi^{2}=484.65, \mathrm{df}=109$, $p<0.001$, RMSEA $=0.078, \mathrm{CFI}=0.96$, TLI $=0.95$, and all factor loadings for the latent variables were significant (ranging from 0.75 to 0.92 ). As shown in Table 1, Cronbach's alpha coefficients of the five subscales of PLCs, i.e., shared purpose, collaborative activity, collective focus on student learning, deprivatized practice, and reflective dialogue were $0.91,0.93,0.89,0.87$, and 0.91 , respectively, which were all higher than 0.80 . The AVE values of the five subscales were $0.76,0.74,0.68,0.71$, and 0.84 , respectively, which were all higher than 0.50 . The CR values of the five subscales were $0.90,0.94,0.89,0.88$, and 0.91 , respectively, which were all higher than 0.70. The square roots of AVE of the five subscales were $0.87,0.86,0.82,0.84$, and 0.92 , respectively, which were all higher than correlations among the latent variables. Therefore, the PLC scale showed good construct validity, convergent validity, discriminant validity, and reliability.

For the teachers' job satisfaction scale, the CFA result showed a satisfactory data fit: $\chi^{2}=40.46, \mathrm{df}=11, p<0.001, \mathrm{RMSEA}=0.068, \mathrm{CFI}=0.99, \mathrm{TLI}=0.98$, and all factor loadings for the latent variables were significant (ranging from 0.60 to 0.91). As shown in Table 1, Cronbach's alpha coefficient of the scale (0.91) was higher than 0.90; AVE value (0.62) was higher than 0.50 ; and $C R$ value (0.92) was higher than 0.70 . Therefore, the teachers' job satisfaction scale had good construct validity, convergent validity and reliability.

\subsection{Descriptive Statistics and Correlations}

Table 1 shows the descriptive statistics and correlations of all variables. For the scale of transformational leadership, the mean score was 4.34 , which was relatively high. For the five subscales of PLC, the mean scores ranged from 4.24 to 4.34 . Specifically, reflective dialogue had the highest score $(\mathrm{M}=4.34, \mathrm{SD}=0.74)$, followed by collective focus on student learning $(\mathrm{M}=4.33, \mathrm{SD}=0.66)$, deprivatized practice $(\mathrm{M}=4.28, \mathrm{SD}=0.71)$ and collaborative activities $(\mathrm{M}=4.26, \mathrm{SD}=0.69)$, and shared purpose had the lowest score $(\mathrm{M}=4.24, \mathrm{SD}=0.69)$. The mean score of teachers' job satisfaction was $3.98(\mathrm{SD}=0.67)$. Meanwhile, significant correlations existed among the seven variables.

\subsection{SEM Results}

A model was set up to examine the relationships among transformational leadership, PLC components and teachers' job satisfaction. SEM results showed that this model had an acceptable data fit: $\chi^{2}=1933.76, \mathrm{df}=485, p<0.001$, RMSEA $=0.072, \mathrm{CFI}=0.92, \mathrm{TLI}=0.91$. Results of SEM analysis are demonstrated in Figure 2.

Results showed that transformational leadership had a significant and positive effect on all the five components of PLCs, specifically shared purpose $(\beta=0.90, p<0.001)$, collaborative activities $(\beta=0.97, p<0.001)$, collective focus on student learning $(\beta=0.94$, $p<0.001)$, deprivatized practice $(\beta=0.95, p<0.001)$, and reflective dialogue $(\beta=0.97$, $p<0.001)$. This indicates that principals' transformational leadership, such as setting directions and goals, developing teachers, and optimizing the organization, can significantly promote the development of PLCs, including shaping a common vision and purpose among teachers, enhancing their collaborative learning, maintaining a collective focus on student learning, fostering shared personal practice and facilitating reflective dialogues. Thus, H1 was supported.

Transformational leadership also had a significant and positive effect on teachers' job satisfaction $(\beta=0.09, p<0.001)$. This suggests that, when a transformational leader sets directions for teachers (such as assisting them with goal setting, clarifying reasons for implementing reform initiatives and demonstrating high expectations), strives to develop people (such as giving teachers individual support, encouraging them to try new ideas and modeling a high level of professional practice), and redesigns the organization (such as advocating teachers' collaborative work and creating conditions for teachers, family and community to participate in school affairs), teachers tend to be more satisfied with the various aspects of their schools. Thus, $\mathrm{H} 2$ was supported. 


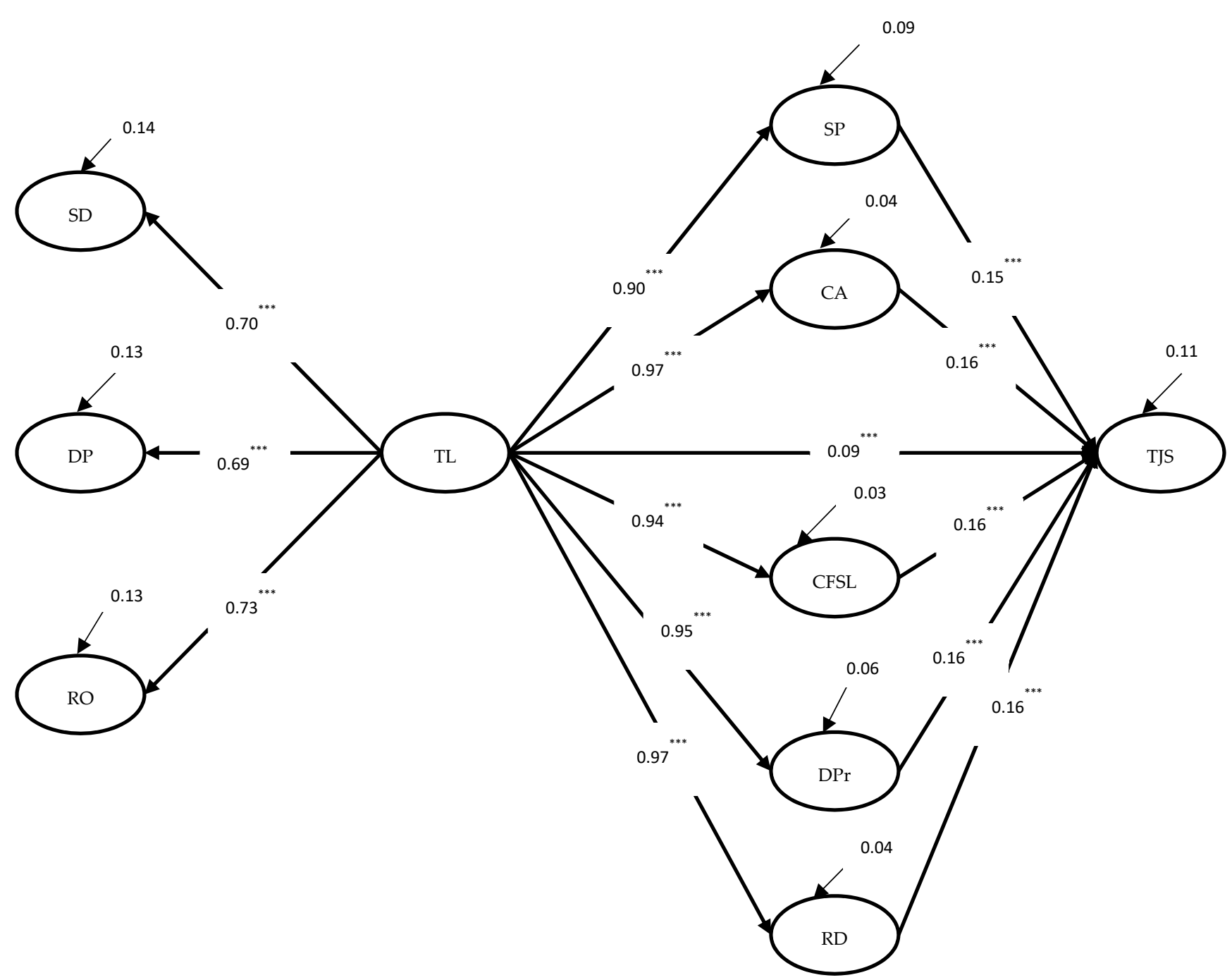

Figure 2. Relationships among transformational leadership, PLC components, and teachers' job satisfaction. Note: ${ }^{* *} p<0.001, \mathrm{SD}=$ setting directions, $\mathrm{DP}=$ developing people, $\mathrm{RO}=$ restructuring the organization, $\mathrm{TL}=$ transformational leadership, $\mathrm{SP}=$ shared purpose, $\mathrm{CA}=$ collaborative activity, $\mathrm{CFSL}=$ collective focus on student learning, $\mathrm{DPr}=$ deprivatized practice, $\mathrm{RD}=$ reflective dialogue, TJS $=$ teachers' ${ }^{\prime}$ job satisfaction.

In terms of the effects of PLC components on teachers' job satisfaction, all five components, namely, shared purpose $(\beta=0.15, p<0.001)$, collaborative activities $(\beta=0.16$, $p<0.001)$, collective focus on student learning $(\beta=0.16, p<0.001)$, deprivatized practice ( $\beta=0.16, p<0.001)$, and reflective dialogue $(\beta=0.16, p<0.001)$ significantly and positively predicted teachers' job satisfaction. This indicates that teachers experience an increased level of job satisfaction if a shared purpose and goal with an unswerving focus on student learning is formed among them, and their collaborative learning, shared practice and collective reflection are well-implemented in their schools. Therefore, $\mathrm{H} 3$ was supported.

\subsection{Mediation Analysis}

Mediation analysis based on 1000 bootstrapping samples was conducted to investigate the mediating effects of PLC components on the relationships between transformational leadership and teachers' job satisfaction. For the mediation results, the standardized estimate of the indirect effect with a $95 \%$ confidence interval (CI) is reported. Table 2 shows the results of the mediation analyses. 
Table 2. Mediation analyses of PLC components on the relationships between transformational leadership and teachers' job satisfaction.

\begin{tabular}{cccccc}
\hline $\begin{array}{c}\text { Dependent } \\
\text { Variable }\end{array}$ & $\begin{array}{c}\text { Independent } \\
\text { Variable }\end{array}$ & $\begin{array}{c}\text { Mediation } \\
\text { Variables }\end{array}$ & $\begin{array}{c}\text { Estimate } \\
\text { (SE) }\end{array}$ & $\mathbf{9 5 \% ~ C I ~}$ & $p$ \\
\hline & & SP & $0.13(.01)$ & {$[0.12,0.14]$} & 0.00 \\
Teachers' job & Transformational & CA & $0.15(.01)$ & {$[0.14,0.16]$} & 0.00 \\
satisfaction & leadership & CFSL & $0.13(.01)$ & {$[0.11,0.14]$} & 0.00 \\
& & DPr & $0.15(.01)$ & {$[0.14,0.16]$} & 0.00 \\
& & RD & $0.15(.01)$ & {$[0.14,0.16]$} & 0.00 \\
\hline
\end{tabular}

Note: $\mathrm{SP}=$ shared purpose, $\mathrm{CA}=$ collaborative activity, CFSL = collective focus on student learning $\mathrm{DPr}=$ deprivatized practice $\mathrm{RD}=$ reflective dialogue.

According to Hayes [100], an indirect effect is significant if zero is not located between the lower and upper boundaries of the $95 \%$ CI. The results showed that all the five PLC components, i.e., shared purpose, collaborative activities, collective focus on student learning, deprivatized practice, and reflective dialogue, were significant mediators between transformational leadership and teachers' job satisfaction. This suggests that principals' transformational leadership can promote teachers' job satisfaction by supporting the practice of PLCs which includes developing a common purpose among teachers, helping them maintain a collective focus on student learning, and providing favorable conditions for their collaborative learning and inquiry, mutual sharing of teaching practice and collective reflection. Therefore, $\mathrm{H} 4$ was supported.

\section{Discussion}

The purpose of this study was to examine the relationships among transformational leadership, PLC components and teachers' job satisfaction from the Chinese principals' perspective. This purpose was achieved with all four questions answered, and all four hypotheses supported. Analyzing the Chinese experience adds to the international literature on the antecedents and consequences of PLCs, and brings the crucial perspective of principals into research on PLCs. The findings are discussed through the following aspects.

\subsection{Effect of Transformational Leadership on PLC Components}

Unlike previous studies that examined the relationship between principal leadership and PLCs from teachers' perspective, this study adopted principals' perspective to explore the effect of transformational leadership on PLCs. Results provide empirical evidence on the crucial role of transformational leadership in PLCs in China [29], and lend credence to findings of studies from teachers' perspectives that leadership matters a lot to the practice of PLCs [17,18,21-23].

The findings of this study suggested a significant effect of transformational leadership on all five components of PLCs (shared purpose, collaborative activity, collective focus on student learning, deprivatized practice, and reflective dialogue). This indicates that principals' transformational leadership practices in terms of setting directions, developing people, and redesigning the organization are important for the development of PLCs. Specifically, while previous studies $[6,60]$ argued that it is important for principals to help teachers in developing a common goal that focuses on student learning in order to implement effective PLCs, this study empirically demonstrated that transformational leadership can result in teachers' shared sense of purpose and collective focus on student learning. This study also indicated that transformational leadership positively affected teachers' collaborative activity, deprivatization of practice and reflective dialogue. This finding agrees with the results of Western research indicating that principal leadership plays a key role in teachers' collaborative learning [31], shared personal practice, and reflective dialogue [25], and corroborates several studies [67] in China that found that principals mattered significantly to teachers' professional collaboration, such as collective lesson planning. 


\subsection{Effects of Transformational Leadership and PLC Components on Teachers' Job Satisfaction}

While previous studies $[72,82]$ demonstrated a positive effect of transformational leadership on teachers' job satisfaction in Western contexts, the current study showed that from Chinese principals' perspective, their transformational leadership can both directly affect teachers' job satisfaction and indirectly affect teachers' job satisfaction through PLCs. Thus, the findings extend our knowledge of transformational leadership as an effective approach of promoting teachers' job satisfaction. This is primarily because that as a critical way of school innovation, transformational leadership supports teachers' intellectual stimulation, enthusiasm of transformation and teaching improvement [55], thus leading to their increased job satisfaction.

Meanwhile, this study found that all the five components of PLCs (shared purpose, collaborative activity, collective focus on student learning, deprivatized practice and reflective dialogue) had significant and positive effects on teachers' job satisfaction. This is similar to the finding of research [90] that collective inquiry and sharing and shared purpose and responsibility significantly and positively predict teachers' job satisfaction. However, it differed from the results of Zheng et al. [92] who used the same model of PLCs as the current study and found that three of the five components of PLCs (shared sense of purpose, deprivatized practices and reflective dialogue) had positive effects on teachers' satisfaction based on teachers' perceptions. This may be attributed to difference between principals' and teachers' perceptions, i.e., principals are more positive about the role of collective focus on student learning and collaborative activity in increasing teachers' job satisfaction. In this sense, this study calls for more studies on PLCs from multiple perspectives [27].

\subsection{Mediating Effects of PLC Components on the Relationship between Transformational Leadership and Teachers' Job Satisfaction}

Previous studies have revealed that the effect of principal leadership on teachers' psychological wellbeing such as efficacy and job satisfaction is indirect, and PLCs or teacher collaboration can act as the mediators $[79,93,96]$. However, whether various components of PLCs have mediating effects on the relationship between transformational leadership and teachers' job satisfaction was underexplored. This study fills this gap by analyzing Chinese principals' perceptions.

Findings showed that all five PLC components (shared purpose, collaborative activity, collective focus on student learning, deprivatized practice, and reflective dialogue) serve as significant mediators between transformational leadership and teachers' job satisfaction. This indicates that principals' transformational leadership plays a key role in teachers' sharing of common purpose, collaborative learning, focus on student learning, shared personal practice, and reflective dialogue [29], which further leads to enhanced teachers job satisfaction. On the other hand, the findings of this study indicated that the direct effect of transformational leadership on teachers' job satisfaction was also significant, i.e., the effect of transformational leadership on teachers' job satisfaction was partly mediated by the five PLC components. Clarifying this issue warrants additional research on the influencing mechanism of transformational leadership on teachers' job satisfaction. For example, other potential mediators such as working atmosphere [101], work engagement [85] procedural justice, and trust [102] could be further detected.

\section{Conclusions and Implications}

The current study examined the relationships among transformational leadership, PLC components, and teachers' job satisfaction from Chinese principals' perspective. Results showed that transformational leadership had a significant effect on all five components of PLCs (i.e., shared purpose, collaborative activity, collective focus on student learning, deprivatized practice, and reflective dialogue), and all five PLC components significantly predicted teachers' job satisfaction. The five components of PLCs significantly and partly mediated the relationship between transformational leadership and teachers' job satisfac- 
tion. The implications of the study for educational leaders and policy makers to promote teachers' job satisfaction in China and other similar contexts are as follows.

First, it is important for leadership training projects to help principals develop transformational leadership. The current study demonstrated that transformational leadership can enhance both all five components of PLCs and teachers' job satisfaction. Therefore, principals' transformational capability in terms of setting directions, developing people, and redesigning the organization should be strengthened. Specifically, leadership training projects need to capacitate principals to properly develop school goals and set high expectations for teachers [58]; provide teachers with intellectual stimulation, targeted support, and good examples of professional values and practice [103]; and establish collaborative structures to motivate and empower teachers towards teaching improvement and school change [54,55].

Second, principals should strengthen their support for the development and sustainment of PLCs. This study found that all the five components of PLCs had significant influences on teachers' job satisfaction. Thus, developing PLCs could be considered an important way of increasing teachers' job satisfaction. Specifically, principals should lead their teachers through a shared purpose and values that unswervingly focus on student learning [6,40], develop collaborative networks among teachers such as critical friend structure [104] to improve teachers' collaborative learning and sharing of practice [59,105], and participate in teachers' professional learning activities to offer professional guidance and promote their collective reflection [2,42]. In this way, it is expected that well-functioning PLCs could be sustained.

This study had several limitations. First, the sampled principals were not randomly selected, and the sample size was relatively small, which limits the generalizability of the findings. Future studies should use more rigorous sampling strategies (e.g., stratified random sampling) to verify the current findings. Second, this study only examined principals' perspectives. Future research could further examine the relationships among transformational leadership, PLCs, and teachers' job satisfaction by combining and comparing principals' and teachers' perceptions.

Author Contributions: Conceptualization, J.Z. and J.X.; data curation, Q.H.; formal analysis, Q.H.; funding acquisition, J.Z.; investigation, J.X.; methodology, J.Z., Q.H. and J.X.; project administration, J.Z.; resources, J.X.; writing—original draft, J.Z. and Q.H.; writing—review and editing, J.Z. and J.X. All authors have read and agreed to the published version of the manuscript.

Funding: This research was funded by the National Social Science Fund of China (grant number: 20CSH033).

Institutional Review Board Statement: The study was conducted in accordance with the Declaration of Helsinki, and approved by the Ethics Committee of Zhejiang University (Protocol code: [2021]094) approved in 11 October 2021.

Informed Consent Statement: Informed consent was obtained from all subjects involved in the study.

Data Availability Statement: Not applicable.

Conflicts of Interest: The authors declare no conflict of interest.

\section{Appendix A}

\section{Transformational leadership scale}

1. I helped clarify the reasons for implementing the reform for my staff.

2. I provide useful assistance to teachers in setting short-term goals for teaching and learning

3. I demonstrate high expectations for my staff.

4. I give teachers support to improve teaching practice.

5. I encourage teachers to consider new ideas for their teaching.

6. I model a high level of professional practice in relation to the reform.

7. I encourage collaborative work among my staff. 
8. I create conditions which allow for wide participation in decisions about school affairs.

9. I plan and work with family and community.

\section{Professional learning community scale}

1. Most teachers in my school share beliefs and values about what the central mission of the school should be.

2. My school goals and priorities are clear.

3. In my school, teachers and the administration are in close agreement on school discipline policy.

4. During the current school year, teachers in my school have frequently received useful suggestions for curriculum materials from their colleagues.

5. During the current school year, teachers in my school have frequently received useful suggestions for teaching techniques and/or student activities from their colleagues.

6. In my school, there is a great deal of cooperative effort among staff members on teaching and learning.

7. Teachers in my school make a conscious effort to coordinate the content of their courses with others.

8. Teachers in my school meet regularly with their colleagues to plan lessons, develop curriculum, evaluate programs, or engage in other collaborative work.

9. The development of students' high level skills (reasoning, problem solving, critical and creative thinking) is an important goal in teachers' teaching in my school.

10. In my school, teachers focus on what and how well students are learning rather than on how they are teaching.

11. Teachers in my school provide authentic teaching and learning for their students.

12. A focused school vision for student learning is shared by most staff in my school.

13. Teachers in my school frequently observe academic performance or review grades/test scores of students in their colleagues' classes.

14. During the current school year, teachers in my school have frequently visited others classrooms to observe and discuss their teaching (excluding monitoring students or substitute others).

15. During the current school year, teachers in my school frequently received meaningful feedback on their performance from supervisors or peers.

16. In a typical planning period with their colleagues, teachers in my school discuss problems of specific students and arrange appropriate help.

17. In a typical planning period with their colleagues, teachers in my school discuss teaching practices and behaviours of team members.

\section{Teachers' job satisfaction scale}

1. Teachers in my school are satisfied with interpersonal relationships.

2. Teachers in my school are satisfied with salaries.

3. Teachers in my school are satisfied with the administrators' work.

4. Teachers in my school are satisfied with professional development opportunities.

5. Teachers in my school are satisfied with facilities.

6. Teachers in my school are satisfied with teaching arrangement.

7. Teachers in my school are satisfied with appraisal mechanism.

\section{References}

1. Harris, A. Leading system transformation. Sch. Leadersh. Manag. 2010, 30, 197-207. [CrossRef]

2. Stoll, L.; Bolam, R.; McMahon, A.; Wallace, M.; Thomas, S. Professional learning communities: A review of the literature. J. Educ. Chang. 2006, 7, 221-258. [CrossRef]

3. McLaughlin, M.W.; Talbert, J.E. Professional Communities and the Work of High School Teaching; University of Chicago Press: Chicago, CA, USA, 2001.

4. Levine, T.H.; Marcus, A.S. How the structure and focus of teachers' collaborative activities facilitate and constrain teacher learning. Teach. Teach. Educ. 2010, 26, 389-398. [CrossRef]

5. Andrews, D.; Lewis, M. The experience of a professional community: Teachers developing a new image of themselves and their workplace. Educ. Res. 2002, 44, 237-254. [CrossRef] 
6. Vescio, V.; Ross, D.; Adams, A. A review of research on the impact of professional learning communities on teaching practice and student learning. Teach. Teach. Educ. 2008, 24, 80-91. [CrossRef]

7. Goddard, Y.L.; Goddard, R.D.; Tschannen-Moran, M. A theoretical and empirical investigation of teacher collaboration for school improvement and student achievement in public elementary schools. Teach. Coll. Rec. 2007, 109, 877-896. [CrossRef]

8. Lomos, C.; Hofman, R.H.; Bosker, R.J. Professional communities and student achievement: A meta-analysis. Sch. Eff. Sch. Improv. 2011, 22, 121-148. [CrossRef]

9. Ramírez-Montoya, M.S.; Loaiza-Aguirre, M.I.; Zúñiga-Ojeda, A.; Portuguez-Castro, M. Characterization of the teaching profile within the framework of education 4.0. Future Internet 2021, 13, 91. [CrossRef]

10. Allen, D. Reconstructing professional learning community as collective creation. Improv. Sch. 2013, 16, 191-208. [CrossRef]

11. Hairon, S.; Dimmock, C. Singapore schools and professional learning communities: Teacher professional development and school leadership in an Asian hierarchical system. Educ. Rev. 2012, 64, 405-424. [CrossRef]

12. Hord, S.M. Professional Learning Communities: Communities of Continuous Inquiry and Improvement; Southwest Educational Development Laboratory: Austin, TX, USA, 1997.

13. Wong, J.L.N. What makes a professional learning community possible? A case study of a Mathematics department in a junior secondary school of China. Asia Pac. Educ. Rev. 2010, 11, 131-139. [CrossRef]

14. Hipp, K.K.; Huffman, J.B. Demystifying Professional Learning Communities: School Leadership at Its Best; Rowman and Littlefield Education: Lanham, MD, USA, 2010.

15. Zhang, J.; Pang, N.S.K. Exploring the characteristics of professional learning communities in China: A mixed-method study. Asia-Pac. Educ. Res. 2016, 25, 11-21. [CrossRef]

16. McLaughlin, M.W.; Talbert, J.E. Building School-Based Teacher Learning Communities: Professional Strategies to Improve Student Achievement; Teachers College Press: New York, NY, USA, 2006.

17. Özdemir, N.; Gün, F.; Yirmibeş, A. Learning-centred leadership and student achievement: Understanding the mediating effect of the teacher professional community and parental involvement. Educ. Manag. Adm. Leadersh. 2021, 17411432211034167. [CrossRef]

18. To, K.H.; Yin, H.; Tam, W.W.Y.; Keung, C.P.C. Principal leadership practices, professional learning communities, and teacher commitment in Hong Kong kindergartens: A multilevel SEM analysis. Educ. Manag. Adm. Leadersh. 2021, 17411432211015227. [CrossRef]

19. Ramírez-Montoya, M.S.; Andrade-Vargas, L.; Rivera-Rogel, D.; Portuguez-Castro, M. Trends for the Future of Education Programs for Professional Development. Sustainability 2021, 13, 7244. [CrossRef]

20. Dalgarno, N.; Colgan, L. Supporting novice elementary mathematics teachers' induction in professional communities and providing innovative forms of pedagogical content knowledge development through information and communication technology. Teach. Teach. Educ. 2007, 23, 1051-1065. [CrossRef]

21. Buttram, J.L.; Farley-Ripple, E.N. The role of principals in professional learning communities. Leadersh. Policy Sch. 2016, 15, 192-220. [CrossRef]

22. Hallinger, P.; Lee, M.; Ko, J. Exploring the impact of school principals on teacher professional communities in Hong Kong. Leadersh. Policy Sch. 2014, 13, 229-259. [CrossRef]

23. Harris, A. Distributed Leadership Matters: Perspectives, Practicalities, and Potential; Corwin Press: Thousand Oaks, CA, USA, 2014.

24. Lomos, C.; Hofman, R.H.; Bosker, R.J. The relationship between departments as professional communities and student achievement in secondary schools. Teach. Teach. Educ. 2011, 27, 722-731. [CrossRef]

25. Vanblaere, B.; Devos, G. Relating school leadership to perceived professional learning community characteristics: A multilevel analysis. Teach. Teach. Educ. 2016, 57, 26-38. [CrossRef]

26. Cranston, J. Holding the reins of the professional learning community: Eight themes from research on principals' perceptions of professional learning communities. Can. J. Educ. Adm. Policy 2009, 90, 1-22.

27. Zhang, J.; Yuan, R.; Yu, S. What impedes the development of professional learning communities in China? Perceptions from leaders and frontline teachers in three schools in Shanghai. Educ. Manag. Adm. Leadersh. 2017, 45, 219-237. [CrossRef]

28. Shumaker, S.; Brownell, A. Toward a theory of social support: Closing conceptual gaps. J. Soc. Issues 1984, 40, 11-36. [CrossRef]

29. Huffman, J.B.; Jacobson, A.L. Perceptions of professional learning communities. Int. J. Leadersh. Educ. 2003, 6, 239-250. [CrossRef]

30. Harris, A.; Jones, M. Professional learning communities and system improvement. Improv. Sch. 2010, 13, 172-181. [CrossRef]

31. Bouwmans, M.; Runhaar, P.; Wesselink, R.; Mulder, M. Fostering teachers' team learning: An interplay between transformational leadership and participative decision-making? Teach. Teach. Educ. 2017, 65, 71-80. [CrossRef]

32. Chou, H.-W.; Lin, Y.-H.; Chang, H.-H.; Chuang, W.-W. Transformational leadership and team performance: The mediating roles of cognitive trust and collective efficacy. Sage Open 2013, 3, 2158244013497027. [CrossRef]

33. Ostroff, C. The relationship between satisfaction, attitudes, and performance: An organizational level analysis. J. Appl. Psychol. 1992, 77, 963. [CrossRef]

34. Dutta, V.; Sahney, S. School leadership and its impact on student achievement: The mediating role of school climate and teacher job satisfaction. Int. J. Educ. Manag. 2016, 30, 941-958. [CrossRef]

35. Visscher, A.J.; Witziers, B. Subject departments as professional communities? Br. Educ. Res. J. 2004, 30, 785-800. [CrossRef]

36. Louis, K.S.; Kruse, S.D. Professionalism and Community: Perspectives on Reforming Urban Schools; Corwin Press: Thousand Oaks, CA, USA, 1995. 
37. Fernandez, C. Learning from Japanese approaches to professional development: The case of lesson study. J. Teach. Educ. 2002, 53, 393-405. [CrossRef]

38. Piggot-Irvine, E. Establishing criteria for effective professional development and use in evaluating an action research based programme. J. Serv. Educ. 2006, 32, 477-496. [CrossRef]

39. DuFour, R. Building a professional learning community. Sch. Adm. 2003, 60, 13-18.

40. Huffman, J. The role of shared values and vision in creating professional learning communities. NASSP Bull. 2003, 87, 21-34. [CrossRef]

41. Little, J.W. Professional community and professional development in the learning-centered school. In Teacher Learning That Matters; Kooy, M., van Veen, K., Eds.; Routledge: New York, NY, USA, 2006.

42. Nehring, J.; Fitzsimons, G. The professional learning community as subversive activity: Countering the culture of conventional schooling. Prof. Dev. Educ. 2011, 37, 513-535. [CrossRef]

43. Leithwood, K.; Aitken, R.; Jantzi, D. Making School Smarter: Leading with Evidence, 3rd ed.; Corwin Press: Thousand Oaks, CA, USA, 2006.

44. $\mathrm{Hu}, \mathrm{Y}$. Exploration of the Function and Character of Teaching and Research Groups of Primary and Secondary Schools in 17 Years since 1949. Teach. Educ. Res. 2011, 23, 50-55. (In Chinese)

45. Paine, L.W.; Fang, Y. Reform as hybrid model of teaching and teacher development in China. Int. J. Educ. Res. 2006, 45, 279-289. [CrossRef]

46. Ryan, J.; Kang, C.; Mitchell, I.; Erickson, G. China's basic education reform: An account of an international collaborative research and development project. Asia Pac. J. Educ. 2009, 29, 427-441. [CrossRef]

47. Wong, J.L.N. Searching for good practice in teaching: A comparison of two subject-based professional learning communities in a secondary school in Shanghai. Comp. A J. Comp. Int. Educ. 2010, 40, 623-639. [CrossRef]

48. Wang, T. Contrived collegiality versus genuine collegiality: Demystifying professional learning communities in Chinese schools. Comp. A J. Comp. Int. Educ. 2015, 45, 908-930. [CrossRef]

49. Wang, D.; Wang, J.; Li, H.; Li, L. School context and instructional capacity: A comparative study of professional learning communities in rural and urban schools in China. Int. J. Educ. Dev. 2017, 52, 1-9. [CrossRef]

50. Zhang, J.; Sun, Y. Development of a conceptual model for understanding professional learning communities in China: A mixed-method study. Asia Pac. Educ. Rev. 2018, 19, 445-457. [CrossRef]

51. Qiao, X.; Yu, S.; Zhang, L. A review of research on professional learning communities in mainland China (2006-2015) Key findings and emerging themes. Educ. Manag. Adm. Leadersh. 2018, 46, 713-728. [CrossRef]

52. Tam, A.C.F. Exploring teachers' beliefs about teacher learning in professional learning communities and their influence on collegial activities in two departments. Comp. A J. Comp. Int. Educ. 2015, 45, 422-444. [CrossRef]

53. Burns, J.M. Leadership; Harper and Row: New York, NY, USA, 1979.

54. Hallinger, P. Leading educational change: Reflections on the practice of instructional and transformational leadership. Camb. J. Educ. 2003, 33, 329-352. [CrossRef]

55. Leithwood, K.; Jantzi, D.; Mascall, B. A framework for research on large-scale reform. J. Educ. Chang. 2002, 3, 7-33. [CrossRef]

56. Longshore, J.M.; Bass, B.M. Leadership and performance beyond expectations. Acad. Manag. Rev. 1985, 12, 756-757. [CrossRef]

57. Yukl, G. An evaluation of conceptual weaknesses in transformational and charismatic leadership theories. Leadersh. Q. 1999, 10, 285-305. [CrossRef]

58. Leithwood, K.; Jantzi, D. Transformational school leadership for large-scale reform: Effects on students, teachers, and their classroom practices. Sch. Eff. Sch. Improv. 2006, 17, 201-227. [CrossRef]

59. DuFour, R. The best staff development is in the workplace, not in a workshop. J. Staff. Dev. 2004, $25,63-64$.

60. Hord, S.M.; Sommers, W.A. Leading Professional Learning Communities: Voices from Research and Practice; Corwin Press: Thousand Oaks, CA, USA, 2008.

61. Carpenter, D. School Culture and Leadership of Professional Learning Communities. Int. J. Educ. Manag. 2015, 29, 682-694. [CrossRef]

62. Mindich, D.; Lieberman, A. Building a Learning Community: A Tale of Two Schools; Stanford Center for Opportunity Policy in Education: Stanford, CA, USA, 2012.

63. DeMatthews, D.E. Principal and teacher collaboration: An exploration of distributed leadership in professional learning communities. Int. J. Educ. Leadersh. Manag. 2014, 2, 176-206.

64. Clarkin-Phillips, J. Distributed leadership: Growing strong communities of practice in early childhood centres. J. Educ. Leadersh. 2011, 26, 14-25.

65. Hassan, R.; Ahmad, J.; Boon, Y. Instructional leadership practice and professional learning community in the Southern Zone of Malaysia. Univers. J. Educ. Res. 2019, 7, 42-50. [CrossRef]

66. Zheng, X.; Yin, H.; Li, Z. Exploring the relationships among instructional leadership, professional learning communities and teacher self-efficacy in China. Educ. Manag. Adm. Leadersh. 2019, 47, 843-859. [CrossRef]

67. Wang, T. School leadership and professional learning community: Case study of two senior high schools in Northeast China. Asia Pac. J. Educ. 2016, 36, 202-216. [CrossRef]

68. Yin, H.; Zheng, X. Facilitating professional learning communities in China: Do leadership practices and faculty trust matter? Teach. Teach. Educ. 2018, 76, 140-150. [CrossRef] 
69. Locke, E. What is job satisfaction? Organ. Behav. Hum. Perform. 1969, 4, 309-336. [CrossRef]

70. Zembylas, M.; Papanastasiou, E. Job satisfaction among school teachers in Cyprus. J. Educ. Adm. 2004, 42, 357-374. [CrossRef]

71. Henke, R.R.; Choy, S.P.; Geis, S.; Broughman, S. Schools and Staffing in the United States: A Statistical Profile, 1993-1994; US Government Printing Office, Superintendent of Documents, Mail Stop SSOP: Washington, DC, USA, 1996.

72. Nguni, S.; Sleegers, P.; Denessen, E. Transformational and transactional leadership effects on teachers' job satisfaction, organizational commitment, and organizational citizenship behavior in primary schools: The Tanzanian case. Sch. Eff. Sch. Improv. 2006, 17, 145-177. [CrossRef]

73. Klassen, R.M.; Usher, E.L.; Bong, M. Teachers' collective efficacy, job satisfaction, and job stress in cross-cultural context. J. Exp. Educ. 2010, 78, 464-486. [CrossRef]

74. Skaalvik, E.M.; Skaalvik, S. Does school context matter? Relations with teacher burnout and job satisfaction. Teach. Teach. Educ. 2009, 25, 518-524. [CrossRef]

75. Chen, J. Chinese middle school teacher job satisfaction and its relationships with teacher moving. Asia Pac. Educ. Rev. 2010, 11, 263-272. [CrossRef]

76. Liu, X.S.; Ramsey, J. Teachers' job satisfaction: Analyses of the teacher follow-up survey in the United States for 2000-2001. Teach. Teach. Educ. 2008, 24, 1173-1184. [CrossRef]

77. Menon, M.; Papanastasiou, E.; Zembylas, M. Examining the relationship of job satisfaction to teacher and organisational variables: Evidence from Cyprus. Int. Stud. Educ. Adm. 2008, 36, 75-86.

78. Crossman, A.; Harris, P. Job satisfaction of secondary school teachers. Educ. Manag. Adm. Leadersh. 2006, 34, 29-46. [CrossRef]

79. Torres, D.G. Distributed leadership, professional collaboration, and teachers' job satisfaction in US schools. Teach. Teach. Educ. 2019, 79, 111-123. [CrossRef]

80. Liu, Y.; Bellibaş, M.Ş.; Gümüş, S. The effect of instructional leadership and distributed leadership on teacher self-efficacy and job satisfaction: Mediating roles of supportive school culture and teacher collaboration. Educ. Manag. Adm. Leadersh. 2020, 49, 430-453. [CrossRef]

81. Cerit, Y. The effects of servant leadership behaviours of school principals on teachers' job satisfaction. Educ. Manag. Adm. Leadersh 2009, 37, 600-623. [CrossRef]

82. Aydin, A.; Sarier, Y.; Uysal, S. The Effect of School Principals' Leadership Styles on Teachers' Organizational Commitment and Job Satisfaction. Educ. Sci. Theory Pract. 2013, 13, 806-811.

83. Malinen, O.P.; Savolainen, H. The effect of perceived school climate and teacher efficacy in behavior management on job satisfaction and burnout: A longitudinal study. Teach. Teach. Educ. 2016, 60, 144-152. [CrossRef]

84. Shen, J.; Leslie, J.M.; Spybrook, J.K.; Ma, X. Are principal background and school processes related to teacher job satisfaction? A multilevel study using schools and staffing survey 2003-2004. Am. Educ. Res. J. 2012, 49, 200-230. [CrossRef]

85. Oubibi, M.; Fute, A.; Xiao, W.; Sun, B.; Zhou, Y. Perceived Organizational Support and Career Satisfaction among Chinese Teachers: The Mediation Effects of Job Crafting and Work Engagement during COVID-19. Sustainability 2022, 14, 623. [CrossRef]

86. Van Maele, D.; Van Houtte, M. The role of teacher and faculty trust in forming teachers' job satisfaction: Do years of experience make a difference? Teach. Teach. Educ. 2012, 28, 879-889. [CrossRef]

87. O'Reilly, P.E. Teachers at Work: Factors Influencing Satisfaction, Retention and the Professional Well-Being of Elementary and Secondary Educators. Ph.D. Thesis, City University of New York, New York, NY, USA, 2014.

88. Høigaard, R.; Giske, R.; Sundsli, K. Newly qualified teachers' work engagement and teacher efficacy influences on job satisfaction, burnout, and the intention to quit. Eur. J. Teach. Educ. 2012, 35, 347-357. [CrossRef]

89. Little, J.W. Locating learning in teachers' communities of practice: Opening up problems of analysis in records of everyday work. Teach. Teach. Educ. 2002, 18, 917-946. [CrossRef]

90. Zhang, J.; Yin, H.; Wang, T. Exploring the effects of professional learning communities on teacher's self-efficacy and job satisfaction in Shanghai, China. Educ. Stud. 2020. [CrossRef]

91. Zhang, J.; Yuan, R. How can professional learning communities influence teachers' job satisfaction? A mixed-method study in China. Teach. Teach. 2020, 26, 229-247. [CrossRef]

92. Zheng, X.; Shen, A.; Yin, H. What kind of professional learning communities do teachers need?-Based on a survey of teachers' teaching satisfaction and sense of teaching effectiveness. Glob. Educ. 2018, 47, 77-88. (In Chinese)

93. Goddard, R.; Goddard, Y.; Kim, E.S.; Miller, R. A theoretical and empirical analysis of the roles of instructional leadership, teacher collaboration, and collective efficacy beliefs in support of student learning. Am. J. Educ. 2015, 121, 501-530. [CrossRef]

94. Joo, Y.H. The effects of distributed leadership on teacher professionalism: The case of Korean middle schools. Int. J. Educ. Res. 2020, 99, 101500. [CrossRef]

95. Luyten, H.; Bazo, M. Transformational leadership, professional learning communities, teacher learning and learner centred teaching practices; Evidence on their interrelations in Mozambican primary education. Stud. Educ. Eval. 2019, 60, 14-31. [CrossRef]

96. Voelkel, R.H., Jr. Causal relationship among transformational leadership, professional learning communities, and teacher collective efficacy. Int. J. Leadersh. Educ. 2019, 1-22. [CrossRef]

97. Zhang, J.; Teng, M. Exploring the Influence of Principal Leadership on Professional Learning Communities: A Mixed-method Study in China. Educ. J. 2021, 49, 29-49. (In Chinese) 
98. Zheng, X.; Yin, H.; Liu, Y.; Ke, Z. Effects of leadership practices on professional learning communities: The mediating role of trust in colleagues. Asia Pac. Educ. Rev. 2016, 17, 521-532. [CrossRef]

99. Kline, R. Methodology in the Social Sciences: Principles and Practice of Structural Equation Modeling, 2nd ed.; Guilford Press: New York, NY, USA, 2005.

100. Hayes, A.F. Beyond Baron and Kenny: Statistical mediation analysis in the new millennium. Commun. Monogr. 2009, 76, 408-420. [CrossRef]

101. Kiboss, J.K.; Jemiryott, H.K. Relationship between Principals' Leadership Styles and Secondary School Teachers' Job Satisfaction in Nandi South District, Kenya. J. Educ. Hum. Dev. 2014, 3, 493-509.

102. Ngodo, O.E. Procedural justice and trust: The link in the transformational leadership-organizational outcomes relationship. Int. J. Leadersh. Stud. 2008, 4, 82-100.

103. Ghadi, M.Y.; Fernando, M.; Caputi, P. Transformational leadership and work engagement: The mediating effect of meaning in work. Leadersh. Organ. Dev. J. 2013, 34, 532-550. [CrossRef]

104. Malone, A.; Smith, G. Developing schools as professional learning communities: The TL21 experience. US China Educ. Rev. 2010, 7, 106-114.

105. Lindahl, R.A. Professional learning communities: A feasible reality or a chimera. In Blazing New Trails: Preparing Leaders to Improve Access and Equity in Today's Schools; Alford, J., Perreault, G., Zellner, L., Ballenger, W., Eds.; DEStech Publications Inc.: Lancaster, PA, USA, 2011; pp. 47-58. 